\title{
INOVATIF DAN RAMAH LINGKUNGAN: IMPLEMENTASI PROGRAM CSR MELALUI KEGIATAN BUDIDAYA IKAN
}

\author{
Abdul Aziz \\ UIN Sunan Kalijaga Yogyakarta, aa248453@gmail.com
}

Afry Rakhmadany

Spv. Pertamina FT Rewulu, afryrakhamdany @ pertamina.com

Muhammad Rezky Pratama

CDO Pertamina FT Rewulu, rezkypratama888@gmail.com

\begin{abstract}
Indonesia is very rich in fishery potential. The potential that exists makes fish farming propagate in urban and rural areas which in fact are far from the waters (sea). However, the performance problem of fish farming in the terrestrial environment is one of the inhibiting factors for the development of fish production in Indonesia. PT. Pertamina (PERSERO) Fuel Terminal Rewulu is one of the agents who embrace the community to open up opportunities for environmentally friendly innovations in fish farming in the terrestrial environment. This opportunity was used by the community to create an empowerment program with the name NOT MAIN. The background of these problems and ideas has attracted researchers to describe the implementation of CSR through community empowerment based on innovative and environmentally friendly independent fish farming. This study uses a qualitative method which is presented descriptively. The object of this research is the NOT MAIN program. The subjects in this study were the CDO and the administrators of the NOT MAIN program. Informants were determined by purposive sampling technique. In terms of data collection techniques, it is done by interview, observation, and documentation. The data analysis technique used the Miles and Hubermen model. Next is a test of the validity of the data which is done by using triangulation of sources and methods. The results obtained from this research are that the program is implemented with a bottom-up approach which is then carried out within the scope of community empowerment. This program also produces environmentally friendly technological innovations, namely MBG technology based on IoT (banoo sensor), the use of solar cells (DC systems), and modified RAS (Recirculating Aquaculture System).
\end{abstract}

Keywords:

Innovative, Environmentally Friendly, CSR Implementation

\begin{abstract}
Abstrak
Indonesia sangat kaya akan potensi perikanan. Potensi yang ada menjadikan budidaya ikan merambat di area perkotaan dan pedesaan yang notabennya jauh dari perairan (laut). Meskipun demikian, permasalahan kinerja budidaya ikan di lingkungan daratan menjadi salah satu faktor penghambat perkembangan produksi ikan di Indonesia. PT. Pertamina (PERSERO) Fuel Terminal Rewulu menjadi salah satu agen yang merangkul masyarakat untuk membuka kesempatan adanya inovasi yang ramah lingkungan dalam budidaya ikan di lingkungan darat. Kesempatan tersebut digunakan oleh masyarakat untuk membuat program pemberdayaan dengan nama BUKAN MAIN. Latar permasalahan dan gagasan tersebut menjadi daya tarik peneliti untuk mendeskripsikan implementasi CSR melalui pemberdayaan masyarakat berbasis budidaya ikan mandiri yang inovatif dan ramah lingkungan. Penelitian ini menggunakan metode kualitatif yang disajikan secara deskriptif. Objek penelitian ini yaitu program BUKAN MAIN. Subjek dalam penelitian ini yaitu CDO dan pengurus program BUKAN MAIN. Informan ditentukan dengan teknik Purposive Sampling. Ditunjau dari segi teknik pengumpulan data maka dilakukan dengan wawancara, observasi, dan dokumentasi. Teknik analisis data menggunakan model Miles dan Hubermen. Selanjutnya adalah uji keabsahan data yang dilakukan dengan teknik
\end{abstract}


triangulasi sumber dan metode. Hasil yang didapatkan dari penelitian ini adalah program dilaksanakan dengan pendekataan botton-up yang kemudian program dilakukan dalam ruang lingkup community empowerment. Program ini juga menghasilakn inovasi teknologi yang ramah lingkungan yaitu teknologi MBG berbasis IoT (banoo sensor), penggunaan solar cell (sistem DC), dan modifikasi RAS (Recirculating Aquaculture System).

Kata Kunci:

Inovatif, Ramah Lingkungan, Implementasi CSR

\section{PENDAHULUAN}

Indonesia merupakan negara yang memiliki bentang lautan yang sangat luas. Kurang lebih luas lautan Indonesia adalah 3,25 juta $\mathrm{km}^{2}$ (Pratama 2020). Hal ini menjadikan Indonesia sebagai negara kepulauan dengan potensi kelautan dan perikanan yang sangat besar. Dapat dicontohkan dari data statistik yang menunjukan bahwa jumlah produksi ikan laut yang didaratkan di Pendaratan Ikan Tradisional (PIT) berjumlah 5,32 juta kuintal atau senilai 9,51 triliun rupiah di tahun 2019 (Badan Pusat Statistik Indonesia 2020a). Meskipun mengalami penurunan 180 ribu kuintal volume produksi ikan dari tahun 2018, namun nilai produksi 2019 menigkat sekitar 578 miliar rupiah (Badan Pusat Statistik Indonesia 2020a).

Fantastisnya harga ikan menjadikan trand budidaya ikan meningkat. Selain alasan tersebut peningkatan disebabkan oleh kebutuhan dan permintaan ikan yang bertambah banyak, menghindari over fishing, menghindari permasalahan cuaca, d an lain sebagainya (Tika 2018). Trand budidaya ikan tidak hanya berkutik di laut, namun sudah berkembang hingga wilayah pedesaan hingga perkotaan yang jauh dari laut. Tercatat di tahun 2019 terdapat 279 perusahaan budidaya ikan. Perusahaan tersebut terbagi dalam empat kategori perusahaan yaitu pembenihan, air payau, air tawar, air laut (Badan Pusat Statistik Indonesia 2020b). Tentunya angka tersebut merupakan peningkatan jumlah perusahaan budidaya ikan dari tahun 2018 yang hanya berjumlah 258 .
Terlepas dari peningkatan trand budidaya ikan, adapun permasalahan yang perlu diperhatikan bagi perusahaan ataupun individual dalam pengembangan budidaya ikan. Permasalahan tersebut berkaitan dengan pengelolaan ikan (Fisheries Management), penegakan hukum (law enforcement), dan pelaku perusahaan perikanan (Kementrian PPN/BAPPENAS and Direktorat Kelautan dan Perikanan 2014). Tulisan lainnya juga menjelaskan bahwa umumnya permasalahan budidaya terikat dengan potensi ekonomi, yaitu belum optimalnya pemanfaatan sumberdaya ekonomi berpotensi lokal, rendahnya tingkatnya adopsi teknologi dan transfer teknologi, buruknya kinerja dan usaha, kemudian lambatnya inovasi produk (Hikmayani 2013). Permasalahan tersebut menjadi efek domino terhadap persaingan global yang memaksa pelaku usaha harus menjalankan usaha dengan efisien (Zulhal 2010).

Salah satu penawar dari permasalahan pengembangan budidaya ikan tersebut adalah pembentukan kelompok pemberdayaan yang saling bersinergi dan memiliki gagasan terbarukan. Tentunya hal ini akan sulit terwujud apabila tidak adanya perhatian khusus oleh salah satu pokok elemen sosial yaitu pemerintah, pasar (perusahaan), dan komunitas (Syahyuti 2004). Karena disebutkan bahwa perusahaan menjadi elemen, maka ada salah satu upaya sebagai bentuk tanggung jawab sosial perusahaan 
terhadap lingkungan dan masyarakat (Tim Universitas Katolik Parahyangan 2010). Upaya tersebut dikenal dengan istilah Corporate Social Resposibility (CSR).

Di Kabupaten Bantul terdapat salah satu perusahaan yang menerapkan CSR. Perusahaan tersebut adalah PT. Pertamina (Persero) Fuel Terminal Rewulu yang mengusung program berkaitan dengan budidaya ikan di lingkungan daratan. Program tersebut diberi nama program Budidaya Perikanan Mandiri, Invoatif, dan Ramah Lingkungan (BUKAN MAIN). Dusun Parangdewe, Balecatur, Gamping, Sleman merupakan lokasi program tersebut dijalankan (Corporate Social Resposibility News 2019). Program BUKAN MAIN ini diimplementasikan melalui pendekatan pemberdayaan masyarakat. Sehingga program tersebut tidak dijadikan sebagai obyek melainkan menjadi sebuah subjek dari pembangunan berkelanjutan.

BUKAN MAIN ini tidak hanya nama sebuah program, akan tetapi diinterprestasikan melalui sebuah gagasan pemberdayaan masyarakat yang dapat menyelesaikan permaslahan budidaya ikan. Program ini berupaya mengoptimalkan potensi lokal, mengadopsi teknologi yang ramah lingkungan, meningkatkan kinerja, dan meningkatkan produktivitas ikan. Sebagai upaya menyelesaikan permasalahan budidaya ikan dan mencapai tujuan yang diharapkan maka program ini juga mengupayakan dukungan dari beberapa stakeholders. Berdasarkan hal itu penelitian ini bertujuan untuk mendeskripsikan implementasi CSR PT. Pertamina (Persero) Fuel Terminal Rewulu yang dilakuakan dengan pendekatan pemberdayaan masayarakat melalui program budidaya ikan di lingkungan daratan? Penelitian ini penting karena dapat menjadi bahan pembelajaran dan evaluasi sebuah program pemberdayaan masyarakat berbasis CSR yang dilakukan secara inovatif dan ramah lingkungan. Penelitian yang ada juga belum dapat dideskripsikan secara inklusif terkait mengapa implementasi CSR dilakukan dengan program pemberdayaan masyarakat yang inovatif dan ramah lingkungan. Rumusan masalah dari penelitian ini adalah bagaimana implementasi CSR PT. Pertamina (Persero) Fuel Terminal Rewulu melalui pemberdayaan masyarakat berbasis budidaya ikan mandiri yang inovatif dan ramah lingkungan?

Tanggung jawab sosial perusahaan dikenal juga dengan istilah Corporate Social Responsibility (CSR). Diantaranya banyak pendapat yang menyampiakan bahwa CSR merupakan sebuah kebutuhan perusahaan untuk dapat berinteraksi dengan komunitas lokal sebagai bentuk masyarakat secara menyeluruh (Rudito dan Famiola 2019). Menurut Howard R. Bowen dalam buku yang ditulis oleh Ismail Solihin menyampaikan bahwa CSR merupakan konsep yang mengacu kepada kewajiban perusahaan untuk menjalankan suatu kebijakan, keputusan, atau tindakan yang disesuaikan dengan tujuan dan nilai masyarakatnya (Solihin 2011).

Salah satu bentuk CSR yang ditunjukan untuk keadaan di luar perusahaan adalah pengembangan masyarakat, atau pemberdayaan masyarakat, atau dikenal juga sebagai community development (Rudito dan Famiola 2019). pemberdayaan masyarakat merupakan pembangunan masyarakat yang dibentuk secara sistematis, terencana, dan diarahkan untuk memperluas akses masyarakat dalam mencapai kondisi sosial ekonomi dan kualitas hidup yang lebih baik dari sebelumnya (Rudito, Budimanta, dan 
Prasetijo 2004). Pendapat lainnya menjelaskan bahwa pemberdayaan masyarakat adalah upaya menyiapkan kepada masyarakat berupa sumber daya, kesempatan, pengetahuan, dan keahlian untuk meningkatkan kemampuan diri masyarakat di dalam menentukan masa depan mereka, serta berpartisipasi dan mempengaruhi kehidupan kelompok masyarakatnya (Ife 1995).

Definisi di atas menguraikan bahwa pemberdayaan ditunjukan sebagai upaya mengubah perilaku masyarakat agar mampu berdaya sehingga mencapai kesejahteraannya. Upaya yang perlu dibangun dalam meriah keberhasilan tersebut yaitu agen pemberdayaan dapat melakukan pendekatan bottop-up. Pendekatan tersebut sebagai usaha menggali potensi, masalah, dan kebutuhan masyarakat (Anwas 2019). Penerapan pendekatan dapat dilakukan melalui 5P yaitu: pemungkinan, penguatan, perlindungan, penyokongan, dan pemeharaan (Suharto 2010). Pemungkinan yaitu upaya menciptakan suasana yang memungkinkan potensi masyarakat berkembang secara optimal. Penguatan yaitu memperkuat pengetahuan dan kemampuan agar masyarakat dapat menyelesaikan permasalahan dan memenuhi kebutuhan sebuah kegiatan. Perlindungan yaitu melindungi masyarakat yang rentan agar terhindar dari permaslahan persaingan yang tidak sehat. Penyokong yaitu memberikan bimbingan dan dukungan agar masyarakat terus termotivasi dalam berkarya mengembangkan kegiatannya. Pemeliharaan yaitu memelihara kondisi yang kondusif agar tetap terjadi keseimbangan yang memungkinkan setiap orang memperoleh kesempatan berusaha.

Melalui pendekatan yang demikianlah implementasi pemberdayaan masyarakat dapat mencapai keberhasilannya. Hal itu juga yang perlu diperhatikan dalam implementasi pemberdayaan masyarakat model CSR.
Diketahui terdapat empat model atau pola implementasi CSR yang pada umumnya diterapkan oleh perusahaan di Indonesia (Said dan Abidin 2004). Modal pertama adalah keterlibatan langsung. Model ini, sebagimana perusahaan menjalankan program CSR secara langsung atau menyelenggarakan kegiatan tanggungjawab sosialnya tanpa melalui perantara. Penyelenggaraan kegiatan ini dilaksanakan dan ditugaskan kepada Corporate secretary atau public affair manager. Model kedua adalah melalui yayasan atau organisasi sosial perusahaan. Pada model ini, perusahaan mendirikan sebuah yayasan sendiri. Segala kegiatan yayasan didanai oleh perusahaan, baik melalui dana awal, dana rutinan, dan dana abadi. Model ini meniru model-model perusahaan di negara maju.

Model implementasi CSR yang ketiga adalah bermitra dengan pihak lain. Perusahaan melakukan kegiatan tanggungjawab sosialnya dengan melakukan kerjasama pihak lain, baik dengan instasi pemerintah, lembaga sosial/organisasi (NGO atau LSM), universitas, media massa, dan lembaga lainnya. Kerjasama ini dapat dilakukan, baik dalam pengelolaan dana maupun penyelengaraan kegiatan sosial. Model yang keempat adalah dengan mendukung atau bergabung dalam suatu konsorsium atau lembaga sosial yang telah memiliki kegiatan sosial tertentu. Model ini lebih berorientasi pada pemberian atau biasa disebut dengan dana hibah.

Kemudian secara umum ruang lingkup pemberdayaan masyarakat model CSR terbagi dalam tiga kategori: community relation, community services, community empowerment (Rudito and Famiola 2019). Community Relation yaitu kegiatan yang menyangkut pengembangan 
pemahaman melalui komunikasi dan informasi yang dilakukan pihak-pihak yang memiliki kepentingan. Secara sedehana ruang lingkup tersebut berkutik dalam kegiatan yang bersifat kedermawanan yang dirasa perlu oleh masyarakat dari sudut subjektif perusahaan. Community services yaitu kegiatan pelayanan perusahaan untuk memenuhi kegiatan masyarakat ataupun kepentingan umum. Ruang lingkup tersbut berkatitan dengan peningkatan infrastruktur masyarakat. Dalam teori yang disuguhkan oleh Raharjo memberikan nama berbeda dari ruang lingkup ini yaitu community assistance, namun memiliki kesepahaman yang sama (Raharjo 2013). Community Empowerment yaitu kegiatan yang berkaitan dengan pemberian akses yang lebih luas kepada masyarakat sebagai upaya mencapai kemandiriannya. Ruang lingkup ini berkaitan dengan kegiatan pelatihan dan pemberdayaan masyarakat secara menyeluruh meliputi ruang lingkup yang lain.

Ditinjau dari ruang lingkup pemberdayaan masyarakat model CSR, Zaidi dalam Ambadar memaparkan adanya pergeseran paradigma dalam pelaksanaan CSR (Ambadar 2008). Dalam pelaksanaannya perusahaan memiliki tiga tingkatan program. Pertama, Charity yang berbentuk dorongan amal berdasarkan motivasi keagaman. Kedua, Philantropi yang merupakan dorongan kemanusiaan yang biasanya bersumber dari norma dan etika universal yang berkembang di masyarakat untuk menolong sesama dan memperjuangkan pemerataan sosial. Bisa dikatakan juga bahwa Philantropi merupakan penyelesaian masalah secara parsial. Ketiga, Citizenship yang merupakan motivasi kewargaan demi mewujudkan keadilan sosial berdasarkan prinsip keterlibatan sosial atau membangun daya saing masyarakat.
Permasalahan kinerja dalam industri perikanan diantaranya (Kementrian PPN/BAPPENAS 2016): Pertama, mutu ikan hasil tangkapan. Karakteristik bahan baku sangat mempengaruhi proses pengolahan dan mutu produk akhir yang dihasilkan. Apabila bahan baku bermutu baik maka keunggulan nilai industri sangat besar. Beberapa faktor yang mempengaruhi kondisi mutu bahan baku terdiri dari penerapan Good Handling Pratices (GHdP) pada aktivitas budidaya ataupun penagkapan hingga penanganan di industri. Fasilitas penanganan perikanan yang dipasok untuk industri, serta penerapan sanitasi pada pekerja, peralatan perikanan dan lingkungan.

Tantangan yang kedua adalah jaminan mutu bagi industri pengelolaan berbasis ekspor. Jaminan mutu terhadap bahan baku dan produk adalah hal dasar yang harus dilakukan. Memiliki sertifikasi mutu dan ketertelusuran informasi produk merupakan syarat utama untuk memperoleh kepercayaan konsumen terhadap mutu produk yang dihasilkan. Kemudian, tantangan yang ketiga adalah pelayanan pelanggan. Yang perlu diperhatikan dalam meningkatkan pelayanan terhadap pelanggan adalah keseseuaian produk dengan permintaan pelanggan, ketersediaan pasokan produk untuk konsumen, dan pengiriman produk tepat jumlah dan tepat waktu. Tantangan yang keempat adalah kemampuan teknologi, peran teknologi dalam kegiatan perusahaan untuk meningkatkan kinerja mutu sangat diperlukan. Kemampuan teknologi yang mumpuni juga akan berpengaruh pada mutu produk dan pelayanan pelanggan.

\section{METODE}


Penelitian ini menggunakan metode kualitatif. Metode kualitatif digunakan untuk mendapatkan data yang kaya, serta informasi yang mendalam mengenai suatu isu atau masalah yang akan dipecahkan (Dukeshire dan Thurlow 2002). Menurut Sharan Merriam metode kualitatif merupakan penelitian yang berusaha memahami fenomena berdasarkan pandangan partisipasi atau internal, bukan pendangan sendiri atau eksternal (Merriam 2004). Kemudian penelitian ini disajikan secara deskriptif yang mana menghasilkan data berupa penggambaran dengan kata-kata dari penelitian. Hal ini dilakukan agar mudah dipahami oleh pembaca (Bogdan and Biklen 2007).

Objek penelitian ini adalah program Budidaya Ikan Mandiri, Inovatif, dan Ramah Lingkungan (BUKAN MAIN). Program tersebut berlokasi di Dusun Parangdewe, Balecatur, Gamping, Sleman. Subyek penelitian ini adalah pendamping (CDO PT. Pertamina (Persero) Fuel Terminal Rewulu), dan pengurus program BUKAN MAIN. Informan dalam penelitian ini ditentukan dengan teknik Purposive Sampling. Teknik ini memberikan upaya kepada peneliti untuk mempertimbangkan sampel sumber data, sehingga mempermudah peneliti dalam menjelajahi objek atau situasi sosial yang diteliti (Sugiyono 2018).

Upaya yang dilakukan peneliti dalam mengumpulkan data dapat dilakukan di berbagai setting, sumber, dan berbagai cara. Ditunjau dari segi teknik pengumpulan data maka dilakukan dengan wawancara, observasi, dan dokumentasi. Wawancara yang dilakukan oleh peneliti bersifat semiterstruktur. Ragam wawancara tersebut dilakukan agar peneliti mendapatkan informasi secara terbuka, dimana informan juga dapat memberikan pendapat atau ide-ide mengenai program BUKAN MAIN (Esterberg 2002). Observasi dilakukan peneliti sebagai bentuk ikhtiar dalam mengumpulkan data, sehingga peneliti melakukan observasi partisipasi moderat. Hal ini dimaksudkan bahwa peneliti dalam mengumpulkan data ikut observasi partisipasi di beberapa kegiatan (Stainback and Stainback 1988). Teknik pengumpulan data berikutnya adalah dokumentasi, yaitu data yang bersifat gambar, tulisan, sejarah, dan lain-lain (dll). Upaya tersebut dilakukan sebagai pendukung sebuah data agar semakin kredibel (Bogdan and Biklen 2007).

Teknik analisis data menggunakan model Miles dan Hubermen yang dilakukan secara interaktif dan berlangsung secara berulang, sehingga datanya sudah jenuh. Aktivitas yang dilakukan dalam analisis data yaitu pengumpulan data, penyajian data, dan penarikan kesimpulan (Miles dan Huberman 1992). Setelah data di analisis maka langkah selanjutnya adalah uji keabsahan data yang dilakukan dengan teknik triangulasi sumber dan metode.

\section{HASIL PENELITIAN}

Dusun Perengdawe terletak di kelurahan Balecatur, Kecamatan Gamping, Kab. Sleman DIY. Luas wilayah dusun adalah $6000 \mathrm{~m}^{2}$. Dusun Parangdewe merupakan padukuhan yang berada di wilayah ring I PT. Pertamina (PERSERO) Fuel Terminal Rewulu Yogyakarta. Dusun ini memiliki potensi ekonomi, salah satunya di sektor perikanan. Potensi tersebut diinisiasi oleh seorang masyarakat untuk membuat kolam pada lahan kas desa sebagai usaha perikanan. Maka terbentuklah sebuah kelompok perikanan dengan nama "Kelompok Pembudiaya Ikan (KPI) Varia Mina Makmur”. Adanya potensi dan sumber daya kelompok menjadi perhatian dari PT. Pertamina (Persero) Fuel 
Terminal Rewulu untuk menjadi pelindung dan penyokong terhadap pemungkinan yang telah diciptakan oleh masyarakatnya. Perhatian tersebut berujung pada pelaksanaan tanggung jawab sosial perusahaan yang dikenal sebagai CSR.

Kelompok Varia Mina Makmur telah ada sejak tahun 2009, namun sebelum PT. Pertamina (Persero) Fuel Terminal Rewulu mengimplementasikan programnya pada tahun 2013, kinerja kelompok masih belum optimal. Oleh karena itu, setelah diadakan social mapping yang menggandeng PSdK UGM maka PT. Pertamina (Persero) Fuel Terminal Rewulu mengidentiikasi bahwa terdapat potensi di bidang perikanan, dimana kelompok perikanan telah terbentuk. Tahap identifikasi ini perlu untuk mengetahui kebutuhan atau masalah apa yang terjadi sehingga program yang direncanakan sesuai sasaran. Sejak tahun 2013 PT. Pertamina (Persero) Fuel Terminal Rewulu telah mengimplementasikan program CSR di KPI Varia Mina Makmur mulai dari pendampingan hingga pelatihan dari manajemen administrasi hingga pengelolaan budidaya ikan. Program ini merupakan implementasi pemberdayaan masyarakat dengan model CSR.

Pelaksanaan pemberdayaan masyarakat dengan model CSR di Dusun Parangdewe dikategorikan dalam tingkatan program Citizenship. Hal ini karena adanya keterlibatan sosial yang meliputi individu untuk dapat terlibat dalam organisasi atau kegiatan masyarakatnya. Dengan begitu, partisipasi masyarakat juga akan semakin tinggi dan langkah untuk meningkatkan ekonomi dengan memanfaatkan potensi-potensi yang ada bisa terwujud.

Citizenship di KPI Varia Mina Makmur dilakukan dengan melibatkan tokoh masyarakat sebagai narasumber dalam pelatihan. Eki, selaku Community Development Offiser (CDO) CSR PT.
Pertamina (Persero) Fuel Terminal Rewulu menuturkan, "pelatihan dalam bentuk management kelompok, narasumbernya dari tokoh masyarakat." Selain itu, KPI Varia Mina Makmur juga diperkenalkan dengan teknologi modern dan teknik budidaya ikan yang lebih efektif. Teknologi ini memudahkan pembudidaya ikan KPI Varia Mina Makmur sehingga dapat menghasilkan ikan dan benih ikan yang berkualitas, serta ramah bagi lingkungan.

Strategi yang dilakkan adalah dengan melakukan pendekatan kepada masyarakat secara berkelompok yang bersifat botton-up. Kemudian, CSR memperkenalkan teknologi modern dan teknik budidaya ikan yang lebih efektif kepada masyarakat/anggota kelompok. Usaha ini bertujuan untuk menambah pendapatan warga dan kegiatannya pun tidak terlalu menyita banyak waktu.

Kemudian, pemberdayaan masyarakat oleh PT. Pertamina (Persero) Fuel Terminal Rewulu di KPI Varia Mina Makmur adalah model implementasi dengan cara bermitra dengan pihak lain. CSR PT. Pertamina (Persero) Fuel Terminal Rewulu bermitra dengan akademisi, yaitu pusat energi dan praktisi perikanan air tawar Universitas Gadjah Mada (UGM), Yogyakarta. Pihak praktisi dari UGM berperan memberikan pelatihan dan mendampingi praktik budidaya ikan madiri, inovatif, dan ramah lingkungan sebanyak 4 kali pertemuan dalam satu periode. Bentuk dari pertemuan tersebut adalah pertemuan tatap muka dan praktik langsung di lapangan.

"tidak hanya pendampingan tapi juga pelatihan dan praktek budidaya dibantu dan kerjasama dengan praktisi perikanan dan akademisi (UGM), pendampingan berupa pengecekan air dan uji lab serta monitoring kegiatan budidaya dan pemberian vitamin, pendampingan 
dilakukan setiap minggu dalam satu periode program (setahun) dari bulan maret sampai november."

(Wawancara Eki: PT. Pertamina (Persero)

Fuel Terminal Rewulu)

Peran dan keterlibatan pihak lain dalam pemberdayaan KPI Varia Mina Makmur dapat dilihat dengan analisis Penta Helix. Dalam hal ini ini, peran akademisi sebagai konseptor program teknologi modern guna menghasilkan ikan yang berkualitas dan ramah lingkungan telah terlaksana. Selain itu, Community yang dalam hal ini adalah KPI Varia Mina Makmur telah berperran sebagai katalisator dan penggerak di lapangan. Kelompok ini telah terlibat secara langsung dalam pelaksanaan budidaya ikan mandiri, inovatif, dan ramah lingkungan. Bahkan, kelompok ini telah melakukan evaluasi terhadap program dan berupaya mencari solusi untuk menyempurnakan budidaya ikan.

Pada tahun 2019 PT. Pertamina (Persero) Fuel Terminal Rewulu mengusung program Budidaya Ikan Mandiri, Inovatif, dan Ramah lingkungan. Hal ini dilakukan atas dasar inisiatif anggota KPI Varia Mina Makmur yang ingin mendapatkan benih yang berkualitas dengan biaya produksi yang murah.

“...Program pembenihan dan budidaya nila
atas inisiatif kelompok, yaitu terdorong
untuk mendapatkan benih yang baik dengan
biaya yang murah. Dengan harapan
pendapatan petani ikan meningkat...”

Atas dasar keinginan anggota KPI Varia Mina Makmur sendiri untuk menambah budidaya ikan yang lebih bervariasi seperti ikan lele, gurami, nila, bawa, dan patin. Namun bibit ikan masih membeli dari pasar ikan atau petani di luar lingkungan KPI Varia Mina Makmur. Setelah sering diajak melakukan studi banding di kelompok lain oleh PT. Pertamina (Persero) Fuel Terminal Rewulu. Pembudidaya ikan KPI Varia Mina Makmur mengetahu bahwa harga ikan nila cukup tinggi dan perawatannya mudah. Maka dari itu mereka tertarik untuk berbudidaya ikan nila serta membuktikan agar biaya produksi minimal namun mendapatkan hasil yang berkualitas.

Pada dasarnya program yang dilaksanakan oleh CSR PT. Pertamina (Persero) Fuel Terminal Rewulu adalah untuk memperkenalkan kepada pembudidaya ikan KPI Varia Mina Makmur dengan teknologi modern sehingga para pembudidaya ikan mampu meningkatkan produktivitas ikan yang berkualitas dan tetap ramah lingkungan.

“...dengan pendampingan CSR

Pertamina akhirnya kami berhasil pembibitan nila merah dan saai ini kami tidak mendangkan benih dari luar..."

Sesuai tujuan awal dari program budidaya ikan yaitu untuk meningkatkan gizi masyarakat Parangdawe. Kemudian KPI Vari Mina Makmur ingin melangkah lebih maju lagi yaitu untuk menghasilkan benih dan bibit ikan yang unggul denagn dilanjutkan program budidaya ikan mandiri, dan inovatif, dan ramah lingkungan. Sesuai pernyataan Gito, sebagai berikut:

“...untuk mendapatkan benih yang sehat, baik, dan mengurangi tingkat stres benih ikan. Dan untuk meminimalis biaya produksi dengan harapan margin petani dan kelompok bisa meningkat..."

(Wawancara Gito: Ketua KPI Varia Mina Makmur)

Impelementasi pemberdayaan oleh

CSR PT. Pertamina (Persero) Fuel Terminal Rewulu ini mengupayakan sebuah solusi yang diinginkan oleh masyaakat serta menyelesaikan permasalahan kinerja di bidang produksi perikanan. Program ini merupakan program di bidang perikanan dengan menggunakan teknologi ramah lingkungan. Teknologi ini berupa teknologi MBG kombinasi IoT, penggunaan solar cell, dan modifikasi RAS (Recirculating Aquaculture System). Program ini diterapkan mulai dari 
pembenihan/pembibitan sampai ikan siap panen. Inovasi yang dilakukan dilakukan dengan perbandingan 2 sistem agar menunjukan teknologi seperti apa yang lebih efisien dan ramah lingkungan.

Dalam pelaksanaannya dilakukan penelitian yang dibantu oleh pertanian UGM dengan beberapa ujicoba secara bertahap. Pertama, ujicoba MBG kombinasi IoT ini dilakukan dengan menggunakan 2 kolam ikan yang diisi dengan ikan nila. Untuk membuktikan penggunaan mana yang lebih efisiesn antara MBG dengan banoo Sesor atau MBG dengan timer. Maka kolam satu digunakan pompa aktif dengan banoo sensor dan kolam 2 berisisi pompa aktif dengan timer. Berdarkan penggunaan daya yang digunakan Hasil perhitungan menunjukkan bahwa MBG banoo sensor membutuhkan 24kWh untuk menaikkan 1 ppm, sedangkan MBG timer membutuhkan $42 \mathrm{kWh}$ untuk menaikkan 1 ppm. Kemudian perbandingan kadar oksigen terlarut dalam dua sistem tersebut menunjujan MBG banoo sensor akan aktif jika DO berada di bawah 7 ppm dan akan mati jika di atas 9 ppm, sedangkan MBG timer selalu menyala pukul 20.00 dan mati pukul 08.00. Dari hasil pengamatan dan penelitian yang dibantu oleh perikanan UGM menunjukan bahawa penggunaan MBG banoo $57 \%$ lebih efisien dibanding penggunaan MBG dengan timer.

Kedua, penggunaan sistem baru instalasi panel surya di kolam ikan Dusun Pereng Dawe. Inovasi ini dilakukan dengan penambahan solar cell dengan daya serap cahaya/panas matahari lebih baik dari solar cell sebelumnya. Pada awalnya hanya menggunakan sistem AC, namun saat ini ditambahkan sistem DC. Terbukti bahwa dengan sistem DC baru dapat menghasilkan 3.93 Wh energi pada satu Wp panel surya, sedangkan sistem AC menghasilkan 3,69 $\mathrm{Wh} / \mathrm{Wp}^{\mathrm{pv}}$. Perlu adanya penambahan

konstanta 0,95 pada sistem AC, hal ini dikarenakan Wh dihitung juga pada sisi input charge controller, dengan menimbang 95\% efisiensi pada charge controller dan inverter. Sedangkan energi pada sistem DC langsung diukur setelah stage power converter, sehingga efisiensi power converter sudah termasuk didalamnya tanpa mendapat pengurangan energi. Jika dibandingkan dengan energy PLN efisiensi energi listrik selama program berlangsung (Januari-September 2019), memiliki efisiensi sebesar $41,03 \mathrm{kWh}$, dengan reduksi emisi sebesar 38,12 $\mathrm{kg}$ CO2e.

Gambar 1

(MBG Kombinasi IoT)

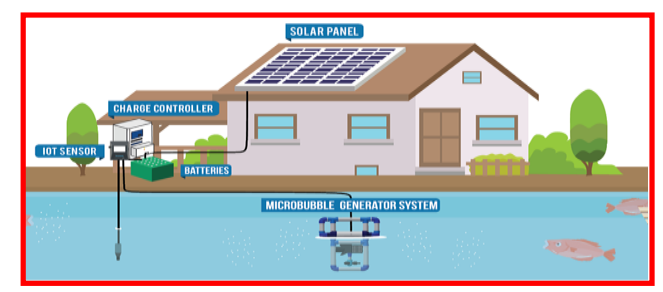

Gambar 2

(Panel Surya)
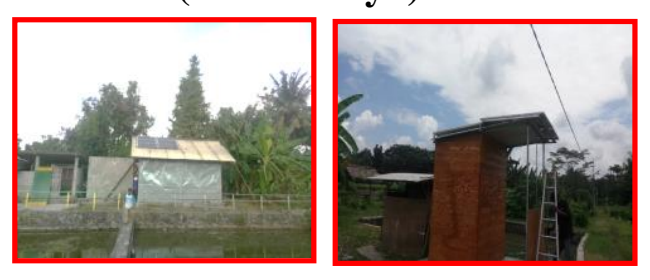

Ketiga, Modivikasi RAS (Resirculating Aquaculture System) yaitu kolam bak pembibitan/pembenihan ikan dilakukan dengan perombakan wadah filter yang mampu meresirkulasikan dan membersihkan air di dalam kolam bak lebih cepat dan efisien. Apliikasi RAS ini mampu mengurangi limbah amoniak yang terkandung di dala air kolam pembibitan (pendederan) selain itu juga dapat menghemat penggunaan air sebanyak 54 $\mathrm{m}^{3}$. Karena apabila menggunakan resirkulasi air konversional total air yang dibuang dalam satu minggu adalah $1.5 \mathrm{~m}^{3}$, 
sedangkan sistem RAS hanya membuang 0.15 $\mathrm{m}^{3}$.

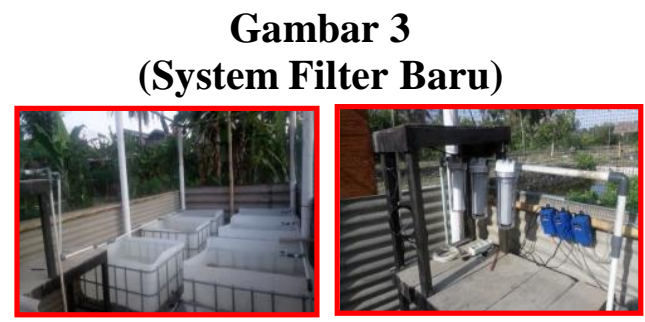

Program ini dijalankan sejak bulan Maret hingga November 2019 periode satu tahun. CSR melakukan pendampingan dan pelatihan kepada KPI Varia Mina Makmur dengan bekerjasama dengan pihak akademisi UGM. Kegiatan pendampingan ini berupa disukusi formal yaitu pertemuan rutinan antara kelompok dan pihak CSR setiap bulannya dan diskusi non-formal yang dilakukan di kolam ikan serta dilakukan studi banding ke kelompok perikanan lain. Tekonologi Banoo dan inovasi sitem DC oleh masyarakat pembudidaya ikan. Begitu juga dengan sistem RAS yang memanfaatkan air sebagai media pemeliharaan secara berulang-ulang dan mengurangi limbah perikanan dengan mengendalikan beberapa indikator kualitas air agar tetap pada kondisi prima. Sehingga sistem RAS ini merealisasikan Budidaya Ikan yang ramah lingkungan. Dari data tahun 2019 terdapat bibit yang sudah berikan sebanyak 10 $\mathrm{Kg}$ atau sebanyak 700 ekor bibit Glondongan (tahap pembesaran) dan sekitar $125 \mathrm{Kg}$ pupuk kandang untuk 6 kolam yang memakai pupuk kandang dari petani pada proses persiapan kolam. Program ini dikelola oleh KPI Varia Mina Mandiri dengan baik sesuai dengan tujuan awal.

“...Perkembangannya bagus, kami saat ini sudah tidak lagi mnedatangkan benih dari luar. Bahkan kelompok sudah bisa memenuhi kebutuhan anggota dan kelompok mendapatkan margin lebih dan menjual benih ikan ke anggota. Anggota kelompok mendapatkan benih yang lebih baik dan sehat dengan harga yang lebih murah dibandikngkan dengan harga di luar kelompok..."
(Wawancara Gito: Ketua KPI Varia Mina Makmur)

“...Bagi Kelompok, terbentuknya kelompok kader dimana kelompok ini secara bersama-sama/gotong royong mengelola kolam dan saat inii sudah dilakukan panen raya. Hasil panen ternyata ada keuntungan yang lumayan bagi kelompok kader. Sedangkan bagi individu, termotivasinya anggota, khususnya kelompok kader untuk budidaya ikan khususnya nila. Kaerena anggota sudah merasakan ada hasilnya..."

(Wawancara Eki: PT. Pertamina (PERSERO) Fuel Terminal Rewulu)

Program pemberdayaan perikanan di dusun Perengdawe, memudahkan pengelola dalam berkegiatan. Hal ini dikarenakan dalam budidaya pembesaran hanya membutuhkan 2,5 bulan yang berarti dalam satu tahun bisa panen sebanyak 3 kali untuk jenis ikan nila nilasa. Ikan jenis tersebut sudah terdapat di dalam 9 kolam yang sudah berjalan yang di isi sebanyak $20 \mathrm{~kg}$ per kolam. Jika di hitung asset selama 2,5 bulan kurang lebih menghabiskan sebanyak 4 -8 sak pakan, dengan target kualitas ikan mencapai berat total untuk 1 kolam adalah 1-2 kwintal dengan penjualan 4-7 ekor/kg sekitar Rp 32.000. Tidak hanya di ukur dari tingkat produktivitas budidaya ikannya saja tetapi CSR PT. Pertamina (Persero) Fuel Terminal Rewulu bekerjasama dengan jurusan PSdK dalam penelitian Indeks Kepuasan Masyarakat (IKM). Hasil yang didapatkan dari penilaian IKM tersebut terkategori sangat baik dengan nilai 3.07 dan juga Multiplayer Efect terhadap peningkatan ekonomi yang cukup signifikan bagi petani ikan di desa tersebut.

\section{KESIMPULAN}

Impelemntasi CSR PT. Pertamina (Persero) Fuel Terminal Rewulu melalui pemberdayaan masyarakat berbasis 
budidaya ikan mandiri yang inovatif dan ramah lingkungan begitu memperhatikan potensi lokal masyarakatnya. Hal tersebut dibuktikan sebelum dibuatkannya program pembangunan berkelanjutan dilakukan sebuah kegiatan social mapping. Pendekatan yang dilakukan juga bersifat botton-up yaitu memperhatikan potensi, pemaslahan, serta menampung aspirasi yang memang dibutuhkan oleh masyarakatnya. Sehingga program BUKAN MAIN dieksekusi melalui ruang lingkup community empowerment (pemberdayaan masyarakat). Implementasi CSR juga menganut model bermitra dengan pihak lain, serta berada pada tingkatan program citizenship. Sehingga pemberdayaan masyarakat program BUKAN MAIN disuguhkan dengan inovasi teknologi yang ramah lingkungan yaitu teknologi $\mathrm{MBG}$ berbasis IoT (banoo sensor), penggunaan solar cell (sistem DC), dan modifikasi RAS (Recirculating Aquaculture System).

Pada teknologi MBG banoo sensor, MBG akan aktif ketika DO di bawah 7 ppm dan akan mati jika di atas 9 ppm. MBG dengan banoo membutuhkan 24kWh untuk menaikkan 1 ppm. Penilaian ini menunjukan bahwa penggunaan MBG dengan banoo 57\% lebih efisien dibanding penggunan MBG dengan timer. Penggunaan solar cell sistem DC lebih efisien di bandingkan sistem AC, karena sistem DC menghasilkan 3.93Wh energi sedangkan sistem AC menghasilkan 3.69 Wh energi. Modifikasi sistem RAS terbukti berdampak positif pada lingkungan hidup karena mampu menghemat penggunaan air sebanyak $54 \mathrm{~m} 3$. Ketiga inovasi yang ramah lingkungan ini menunjukan bahwa implementasi pemberdayaan model CSR PT. Pertamina (Persero) Fuel Terminal Rewulu dikemas dengan memperhatikan profit, planet, people.

\section{DAFTAR PUSTAKA}

Ambadar, Jackie. 2008. CSR Dalam Praktik Di Indonesia. Edited by Dodi Mawardi. xv. Jakarta: Elex Media Komputindo.

Anwas, Oos M. 2019. Pemberdayaan Masyarakat Di Era Global. Bandung: Alfabeta.

Badan Pusat Statistik Indonesia. 2020a. Statistik Pendaratan Ikan Tradisional (PIT) 2019. Jakarta: Badan Pusat Statistik.

-. 2020b. "Statistik Perusahaan

Perikanan (Statistics of Fishery Establishment) 2019." Jakarta.

Bogdan, Robert C., and Sari Knopp Biklen. 2007. Qualitative Research for Education: An Introduction to Theories and Methods. 5th ed. Boston: Pearson Education.

Corporate Social Resposibility News. 2019.

“'Bukan Main', Program Pertamina Dukung Kelompok Perikanan Sleman.” Pertamina.Com. 2019. https://www.pertamina.com/id/newsroom/csr-news/-bukan-main-programpertamina-dukung-kelompok-perikanansleman.

Dukeshire, Steven, and Jennifer Thurlow. 2002. Understanding the Link Between Research and Policy. Rural Communities Impacting Policy Project. https://docplayer.net/142310-

Understanding-the-link-betweenresearch-and-policy.html.

Esterberg, Kristin G. 2002. Qualitative Methods in Social Research. New York: McGRAW-HILL.

Hikmayani, Yayan. 2013. "Permasalahan Yang Dihadapi Masyarakat Dan Peran KIMBis Dalam Kehidupan Masyarakat Kota Tegal." Buletin Riset Sosek Kelautan Dan Perikanan 8 (2): 67-74.

Ife, James Wiliam. 1995. Community Development Creating Community 
Alternatives, Analiysis and Pratice. Melbourne: Longman.

Kementrian PPN/BAPPENAS. 2016. Kajian

Strategi Industrialisasi Perikanan Untuk Mendukung Pembangunan Ekonomi Wilayah. Direktorat Kelautan dan Perikanan.

Kementrian PPN/BAPPENAS, and Direktorat Kelautan dan Perikanan. 2014. "Kajian Strategi Pengelolaan Perikanan Berkelanjutan.” Jakarta.

Merriam, Sharan. 2004. "The Role of Cognitive Development in Mezirow's Transformational Learning Theory." Adult Education Quarterly: A Journal of Research and Theory 55 (1): 1-99. https://doi.org/https://doi.org/10.1177/0741 713604268891.

Miles, Matthew B., and A. Michael Huberman. 1992. Analisis Data Kualitatif: Buku Sumber Tentang Metode-Metode Baru. Jakarta: Penerbit Universitas Indonesia (UI -Press).

Pratama, Oki. 2020. "Konservasi Perairan Sebagai Upaya Menjaga Potensi Kelautan Dan Perikanan Indonesia." Direktorat Jendral Pengelolaan Ruang Laut. 2020. https://kkp.go.id/djprl/artikel/21045-

konservasi-perairan-sebagai-upayamenjaga-potensi-kelautan-dan-perikananindonesia.

Raharjo, Santoso Tri. 2013. Relasi Dinamis Antara Perusahaan Dengan Masyarakat Lokal: Kajian Mengenai Kegiatan Tanggung Jawab Sosial Industri Geothermal Kepada Masyarakat Lokal. Bandung: UNPAD Press. lppm.unpad.ac.id\%0D.

Rudito, Bambang, Arief Budimanta, and Adi Prasetijo. 2004. Corporate Social Responsibility: Jawaban Bagi Model Pembangunan Indonesia Masa Kini. Jakarta: Indonesia Center for Sustainable Development.
Rudito, Bambang, and Melia Famiola. 2019. Corporate Social Resposibility. Bandung: Rekayasa Sains.

Said, Zaim, and Hamid Abidin. 2004. Menjadi Bangsa Pemurah: Wacana Dan Praktek Kedermawanan Sosial Di Indonesia. Jakarta: Piramida.

Solihin, Ismail. 2011. Corporate Social Responsibility: From Charity to Sustainability. Jakarta: Salemba Empat.

Stainback, Susan, and William Stainback. 1988. Understanding and Conducting Qualitative Research. Reston: Council for Exceptional Children.

Sugiyono. 2018. Metodelogi Penelitian Evaluasi. Edited by Yuyun Yuniarsih. Bandung: Alfabeta.

Suharto, Edi. 2010. Membangun Masyarakat Memberdayakan Rakyat: Kajian Strategis Pembangunan Kesejahteraan Sosial Dan Pekerjaan Sosial. Edited by Aep Gunarsa. Bandung: Refika Aditama.

Syahyuti. 2004. "Pemerintah, Pasar, Dan Komunitas: Faktor Utama Dalam Pengembangan Agribisnis Di Pedesaan." Forum Penelitian Agro Ekonomi 22 (1): 54-62.

Tika, Echa. 2018. "Hal Penting Mengapa Budidaya Perikanan Perlu Dikembangkan Dengan Baik Di Indonesia?" IlmuBudidaya.Com. 2018. https://ilmubudidaya.com/mengapabudidaya-perikanan-perludikembangkan.

Tim Universitas Katolik Parahyangan. 2010. "Corporate Social Responsibility: Konsep, Regulasi, Dan Implementasi." https://www.academia.edu/11786637/C ORPORATE_SOCIAL_RESPONSIBIL ITY_KONSEP_REGULASI_DAN_IMP LEMENTASI_Oleh.

Wawancara Eki : PT. Pertamina (PERSERO) Fuel Terminal Rewulu 
Wawancara Gito: Ketua KPI Varia Mina Makmur

Zulhal. 2010. Knowledge \& Innovation: Platform Kekuatan Daya Saing. Jakarta: PT Gramedia Pustaka Utama. 